large. Cheeks not one-third the vertical diameter of the eyes. Antennae yellowish red. Palpi light yellow. Thorax dark reddish brown, opaque, the mesonotum with a pair of stripes and the lateral margins yellowish white pollinose. Pleurae with a similar light colored stripe at about its middle. Abdomen deep reddish brown or black, opaque, with the lateral margins opaque light yellow; ovipositor yellow. Legs wholly light yellow; the four anterior femora only a little thickened; tip of hind tibrae and the distal joints of all the tarsi brown; hind femora considerably thickened; hind tibiae arcuate, not dilated, with a few short bristles on the outer side; all the femora with spiny bristles on the under side distally. Wings brownish, lighter colored along the costa; first posterior cell elongate. Scutellum yellowish, whitish pollinose. Length 8-9 $\mathrm{mm}$.

Two specimens, Chapada, Brazil, H. H. Smith.

\title{
A PSYLLID LEAF-GALL ON CELTIS, PROBABLY PACHYPSYLLA CELTIDIS-PUBESCENS RILEY.
}

\section{BY C. H. TYLER TOWNSEND, LAS CRUCES, N. M.}

On May I4, I892, I found at Riley's water, at western base of the Organ Mountains, some small leaf-galls on Celtis occidentalis. The tree was determined by Mr. Walter H. Evans, who was with me at the time. The galls at that date showed on the upper side of the leaves as small swellings about 3 to $5 \mathrm{~mm}$. in diameter, with a pit in the center, thus appearing like raised circles. On the under side they showed simply as smaller warts covered with fine rather long pubescence. Several galls occurred on the same leaf.

On Nov. 26, 1892, in the north end of the same range, south of San Augustine and part way up from the base of the mountains, there were found numerous fallen leaves of Celtis containing fully developed galls of this species. As many as 20 galls occurred on one small leaf. There were occasionally some double galls. The fallen leaves were green in color, but nearly dry. This gall appears without much doubt to be that of Pachypsylla celtidispubescens Riley, as it agrees well with the description.

The dried galls on the leaves just mentioned measure 2 to $3 \mathrm{~mm}$. in diameter on the lower globular portion. The upper circular rim-like portion is 3 to $4 \mathrm{~mm}$. in diameter. Only galls from which the occupants had emerged were measured. The exit holes are in the side of the pit-like depression on upper surface of leaf. They are elongate openings, so as to allow the egress of the wide-bodied and flattened pupa. Occasionally a gall has a small circular opening, in one case this being in the globular portion of the gall on the under side of the leaf. These mark the exit of a small hymenopterous parasite.

Some of the above dried galls having no exit hole were opened, and some 
dried pupae found within. These may be described as follows:-

Psyllid pupa.-Length (abdomen shrunken), I.2 to I. $4 \mathrm{~mm}$.; width, I to $1.2 \mathrm{~mm}$. The wing pads in their naturally half-spread condition give an apparent width, equaling the somewhat shrunken length; they are distinctly longer than width of thorax. Pupa rather oval or rounded in outline, widest in middle of abdomen; finely and somewhat sparsely pubescent on body, wing-pads and antennae; abdomen long pubescent. Pale yellowish, eyes black; mesonotum, pronotum, and top of head roseate; anterior pair of wing-pads pale rosy yellowish, hind wing-pads paler. Abdomen pale greenish, with an anterior median rosy yellowish area, the terminal portion broadly brownish with a median row of small black spines ending in a spiny tubercle, 13 spines altogether in the row, and one on each side of row on posterior edge of abdomen. Spines are arranged thus: first (anteriorly) three in a triangle with apex posteriorly directed; then three more in a similar triangle; then the bunch of six in three pairs with a larger central one, giving the appearance of a spinigerous tubercle. These spines grow longer and stouter towards posterior end of row. On segment anterior to that bearing the first three above mentioned, there seem to be an additional hardly visible three. But in the larger specimen there is in place of these only one quite conspicuous one of good size. Legs and under side of body pale greenish, sternal and anterior portions yellowish rosy, the legs more or less shaded with same color. Antennae greenish at base, more rosy or pale apically.

Described from two specimens, taken from dried galls found Nov. 26. The galls picked May I4 disclosed nothing.

The very small, elongate, whitish eggs of this psyllid were found on a cluster of young leaves, May I4. The eggs were quite thickly attached to the under surface of the leaf, adhering by one end, and slanted toward the tip of the leaf. A fewer number also occurred on the upper surface. But a considerable number of the justhatched young were found on upper surface, where they were beginning to bury themselves in the substance of the leaf to form their galls.

The Celtis is probably the var. reticulata.

Two small hymenopterous parasites issued from the dried galls above mentioned. They have been determined by Mr. Wm. H. Ashmead as Ceraphron sp., and Tetrastichus sp.

\section{PHTHIRIA SULPHUREA LOEW.}

\section{BY T. D. A. COCKERELL, N. MEX. AGR. EXP. STA.}

Described from the female. About $3 \mathrm{~mm}$. long; yellow, wings hyaline. Head dull chrome yellow, ocelli black, eyes dull purple; proboscis about twice as long as head; face with sparse fine whitish pubescence; antennae chrome yellow; third joint more than twice as long as the other two combined, about twice as long as broad, pointed, but with a small tooth almost at the end, so as to appear bifurcate or deeply emarginate; without bristles.

Thorax pale delicate greenish-yellow, with 

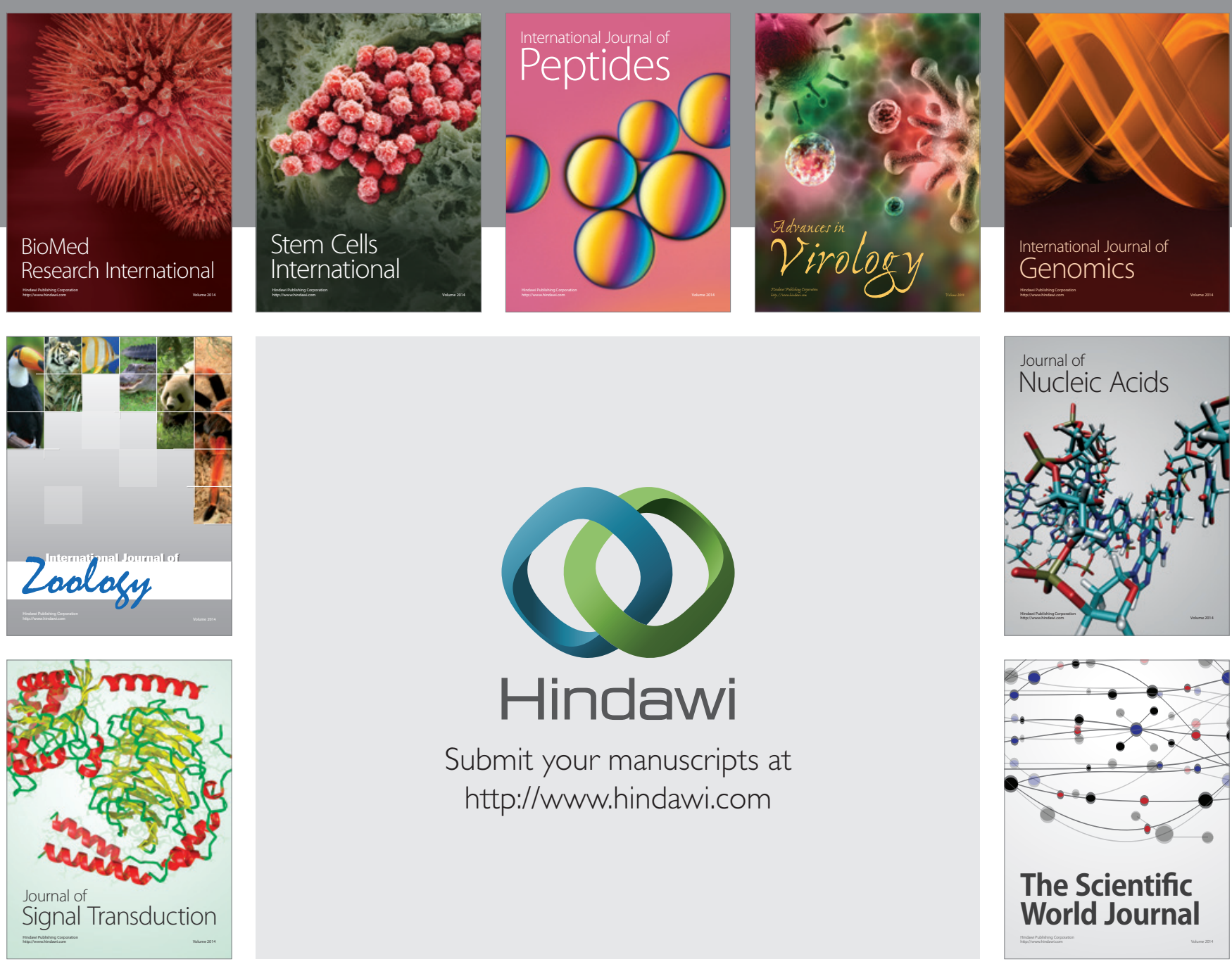

Submit your manuscripts at

http://www.hindawi.com
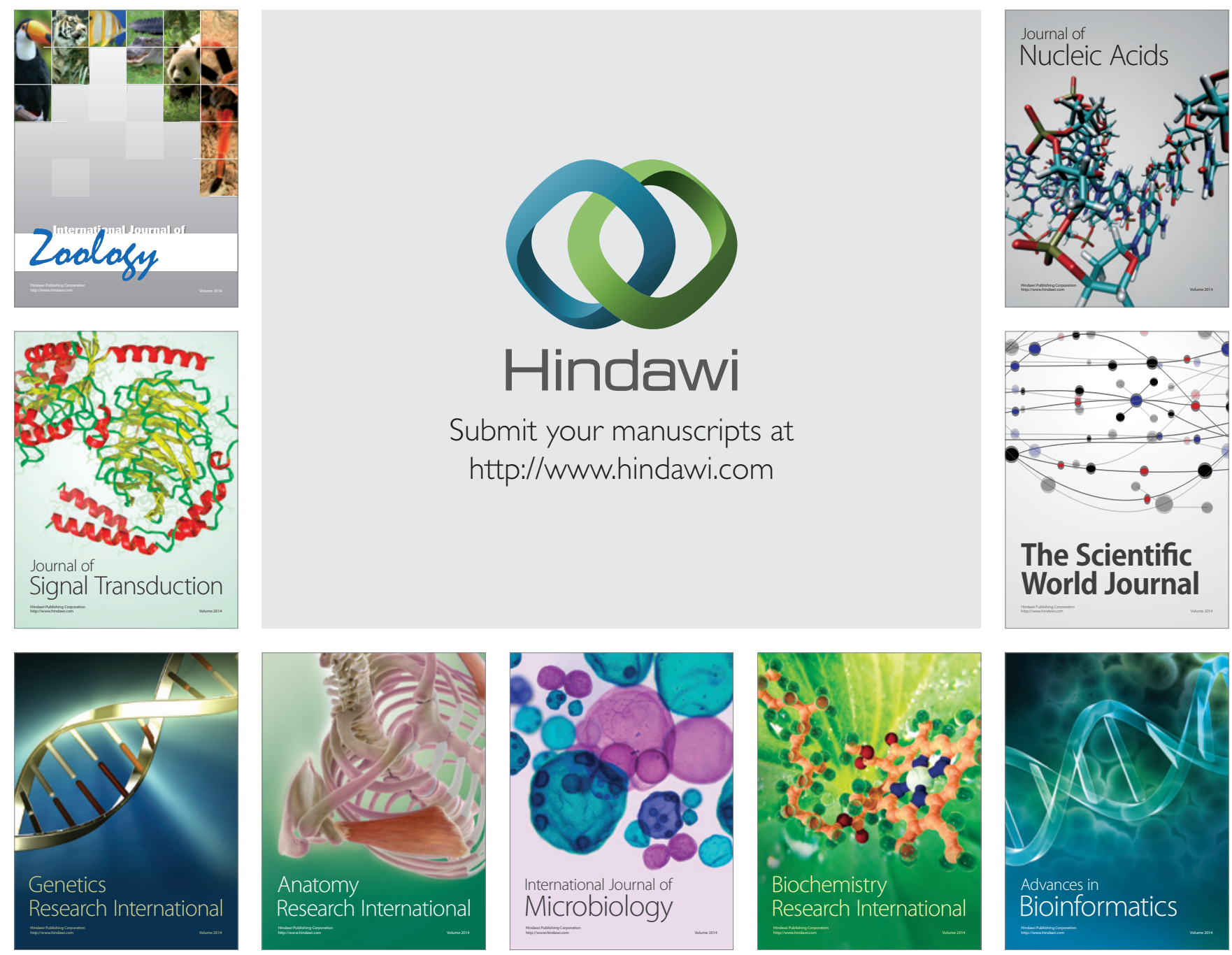

The Scientific World Journal
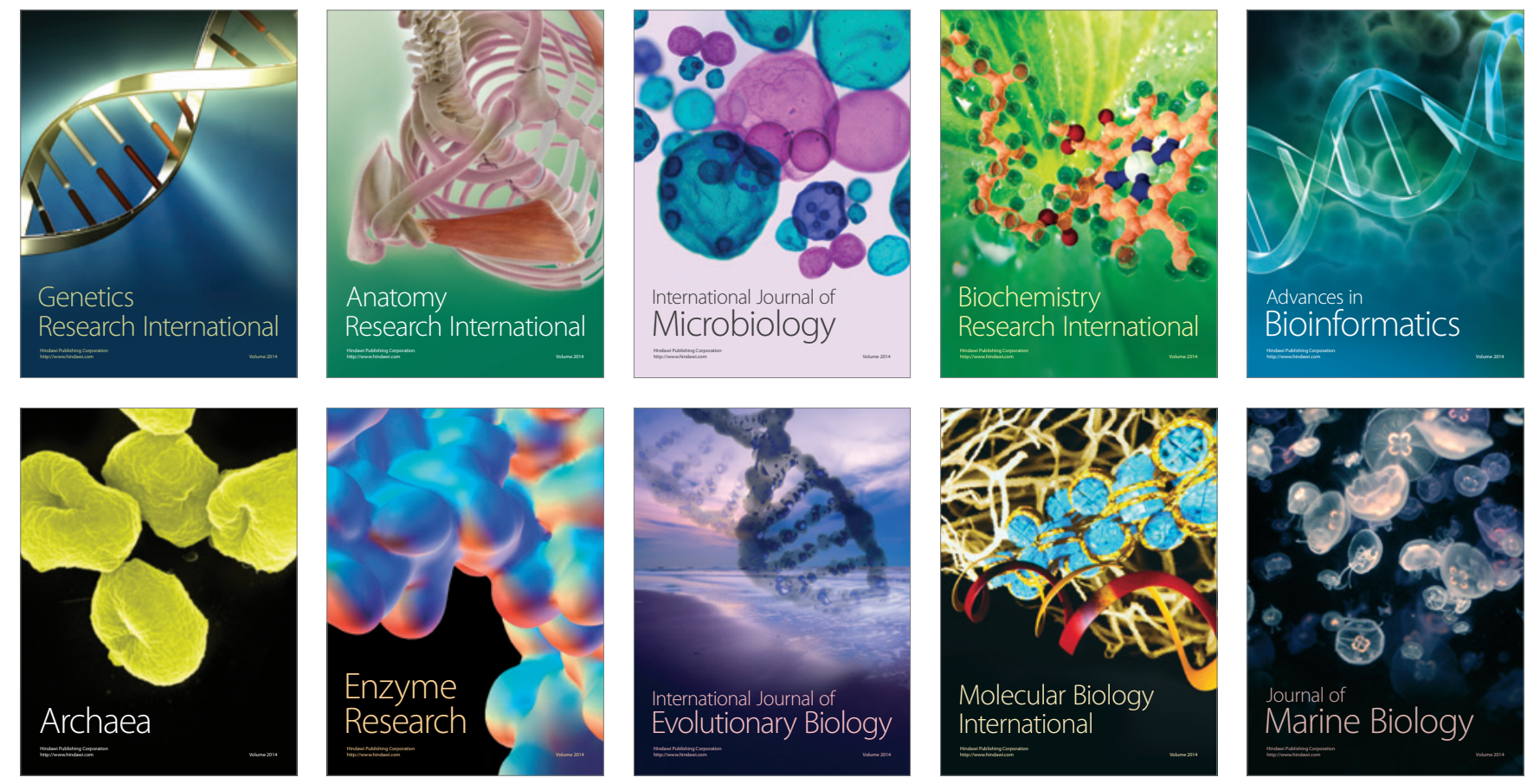